\title{
AGAINST A DIDACTIC READING OF THE PARABASIS IN ARISTOPHANES' FROGS
}

\author{
Nicholas D. Smith \\ Lewis \& Clark College, USA.
}

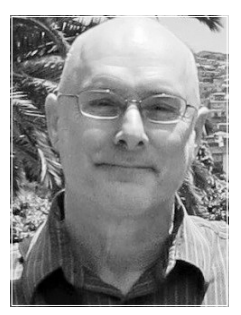

Given its topicality, it is tempting to suppose that one may find important insights into the politics of late 5th C. Athens in Aristophanes' comedies. The problem, I contend, is when scholars think they can discern Aristophanes' own political views simply by supposing that some character in the play (or the chorus leader in the parabasis) directly presents the author's views. As tempting as such an inference sometimes is, it is one that should be made with extreme caution. For each example of what might seem to some scholars as serious political advice, one may find many other instances that cannot possibly be taken to represent Aristophanes' real views in the lines he has written. In this discussion, I take up just one case of political speech in an Aristophanic play, Frogs, and argue (contrary to most existing scholarship) that it should not be interpreted as didacticism. Instead, I argue that Aristophanes gives samples of political advocacy from the most extreme poles of contemporary ideology, in such a way as to highlight how dangerous and foolish such policies would be.

Aristophanes was mocking, not endorsing, the follies that would soon prove to be so ruinous for Athens.

Key-words: Aristophanes, Frogs, parabasis, didacticism, political speech, samples of political advocacy, contemporary ideology, comedy, the author's views.

\section{Frogs and Aristophanic Didacticism}

$\mathrm{G}$ iven its topicality, it is tempting to suppose that one may find important insights into the politics of late $5^{\text {th }} \mathrm{C}$. Ath- ens in Aristophanes' comedies. The problem, I contend, is when scholars think they can discern Aristophanes' own political views simply by supposing that some character in the play (or the chorus leader in the paraba-

1 «The lines [of the parabasis in Frogs] are chanted and sung by the Chorus of Initiates, but they are clearly to be understood as expressing the views of the poet himself» [Griffith 2013: 43]. 
sis) directly presents the author's views ${ }^{1}$. As tempting as such an inference sometimes is, it is one that should be made with extreme caution: For each example of what might seem to some scholars as serious political advocacy, one may find many other instances that cannot possibly be taken to represent Aristophanes' real views in the lines he has written. In this discussion, I take up just one case of political speech in an Aristophanic play, Frogs, and argue that it should not be taken as serious advocacy. My argument goes against the general scholarly consensus.

According to Alan Sommerstein, the parabasis (674-737) of Frogs «is the most political parabasis in the surviving works of Aristophanes» (Sommerstein 13-14) 2 . Sommerstein enumerates several «specific, practical proposals for action in the crisis» including restoration of citizenship to those who had been stripped of it in the wake of the overthrow of the four hundred in 411, and the rejection of current leaders (esp. Cleophon) in favor of those who are «well-born and well-educated» (Sommerstein, 14).

One thing we should note with particular concern in this interpretation is that it attributes to Aristophanes sentiments that align him with the very oligarchic revolutionaries he is taken to want restored to the citizenry. In fact, many of these men were restored ${ }^{3}$ in the autumn of $405^{4}$ and very soon after (in the spring of 404), several of them were again involved in the violent overthrow of Athenian democracy. The upshot of aligning Aristophanes with this faction, accordingly, as Sommerstein himself ruefully puts it, «made him either a willing tool or [an] innocent dupe» (Sommerstein, 23) of those responsible for the terrible events about to happen in Athens ${ }^{5}$. In what follows, I offer an interpretation that provides a more charitable view of what Aristophanes was doing in Frogs.

\section{The «Advice» Given to the Audience}

The parabasis of Frogs gives three specific bits of advice to the Athenian audience: (i) they should replace Cleophon, who is implied to be the son of a Thracian slave woman (680-682), and thus not even a legitimate Athenian citizen ${ }^{6}$; (ii) they should restore full rights of citizenship to all of those who were exiled or disenfranchised for their role in the oligarchic revolution of 411 (689-692), and in fact not just these men, but indeed, anyone who had ever been disenfranchised for any reason should have his rights fully restored (692); and (iii) not only was Athens right to give citizenship to the slaves who fought for Athens at Arginusae ${ }^{7}$ and the Plataeans after $427(693-695,697-700)^{8}$, they should make this standard practice in the future (701705). Let us take each of these up in order.

On the first bit of advice - the replacement of Cleophon - it is worth asking who Aristophanes may have had in mind to serve as the appropriate replacement. The options seem to indicate several possibilities, but it seems reasonable to ask whether any of them is indicated by Aristophanes to count as a good choice. Among those who might be recognized as suitable leaders at that time, the main options would appear to be Ther-

2 K.J. Dover, too, notes the «unusually serious character» of what he finds in the parabasis (1972: 175). MacDowell also characterizes what he finds in the play as «advice» Aristophanes gave to his audience [MacDowell, 1995: 300]. See also [Hubbard, 1991: 207-8];[Sheppard, 1910: 252].

3 See [McDevitt, 1970: 73-79].

4 See [McDevitt, 1970].

5 Elsewhere, Sommerstein give a similar assessment: «We cannot tell whether Aristophanes himself was a willing tool of the conspirators, or whether he too was deceived» [Sommerstein, 2009: 6].MacDowell, too, takes the parabasis to indicate Aristophanes' actual views, and thus concludes (in a vast understatement) that «the serious political advice given in Frogs turned out to be not such good advice as Aristophanes thought» [MacDowell, 1995: 300].

6 See also Plato (Comicus) fr. 61 [in Kassel and Austin 1983].

7 See Hellanicus 23a F 25 in Jacoby 1923, vol. 3.

8 For which, see Isocrates' Panathenaicus 94 [in Norlin 1929] and Demosthenes' Against Neaera 104 (in Kamen 2018). Such special citizenships, however, did not allow them to become archons or priests, but did include voting rights and membership in tribes and demes and full rights to their sons (if born to Athenian mothers). 
amenes or Thrasybulus. But Aristophanes seems to have nothing to say about the latter ... and nothing good to say about the former, who is ridiculed in Frogs as a clever agent who always manages to play to both sides (541), and is also counted as a true Euripidean on the same grounds at $968^{\circ}$, which hardly counts as a compliment in Aristophanes. Theramenes had already gone to seek peace terms from the Spartans at this time, but had not yet returned, and Sommerstein wonders if he was not being regarded as having «deserted to the enemy» (Sommerstein, 22). He might as well have, given his involvement in the oligarchic overthrows of the democracy in 411 and then again in 404 .

We know that both Theramenes and Thrasybulus had worked hard to achieve the recall and pardon of Alcibiades, who is characterized by both contestants in the agon of the play as dangerous and as one (in the words on Aeschylus), who may be worked with only entirely on his own terms and with everyone else ministering to his whims (see lines 1422-1434). If Aristophanes is clearly advocating a change of direction from Cleophon and his followers ${ }^{10}$, accordingly, it would be good to know to whom scholars suppose Aristophanes thought the Athenians should turn. Of course, given the second bit of advice given in the parabasis, it might have been implicit that the democratic leadership of Cleophon should be replaced by the antidemocratic leadership of the oligarchic revolutionaries still in exile, so let us now turn to that part of the parabasis.

One reason the second bit of advice is regarded as Aristophanes' actual political opinion is that the restoration of rights to those who had been disenfranchised was in fact accomplished soon after the production of Frogs ${ }^{11}$. But this is reasoning post hoc ergo propter hoc. The best argument for supposing that what Aristophanes included in his parabasis was actually followed as good advice by the Athenians is offered by MacDowell [MacDowell, 1995: 298-299] who reports two much later sources (Frogs hypothesis I and the Life of Aristophanes) that claim the Athenians crowned Aristophanes with a garland of sacred olive and had Frogs produced again the following year, simply because of what was said about the disenfranchised in the parabasis. Despite misgivings ${ }^{12}$, MacDowell imagines that both sources probably come from Dikaiarchos, who probably had before him the text of an Athenian decree praising Aristophanes for what he had said about the disenfranchised in the parabasis and authorizing an olive garland and a second performance. So we should accept that the passage about the disenfranchised was the main reason for the honour; and since the Athenians would hardly confer such an extraordinary honour for a particular piece of advice without acting on that advice, the decree honouring Aristophanes must belong to the same time as the decree of Patrokleides (the decree that restored rights to those who had been disenfranchised), the autumn of 405 [MacDowell, 1995: 299].

If there were any reliable historical evidence for the decree that MacDowell imagines here, it would certainly help to lend weight to this remarkable speculation. In fact, however, we have only the two very late reports and the evidence actually provided in Aristophanes' play. I suggest that we take a closer look at the latter, for I do not think it supports MacDowell's argument.

First, while the politics in Athens was changing rapidly, it is worth recalling that Cleophon was supported by the democratic faction(s). Those to whom Aristophanes' al-

\footnotetext{
9 «Theramenes was notorious for changing sides» [MacDowell, 1995: 284].

10 Not long after the production of Frogs, Cleophon was arrested and executed [Lysias' Against Agoratus 12, in Lamb 1930].

11 See, for example, MacDowell, who characterizes the decision this way: «in the autumn of 405 [the Athenians] carried out one part of Aristophanes' advice [...] restoring the rights of disenfranchised citizens» [MacDowell, 1995: 298]. Henderson says, «by the decree of Patrocleides the Athenians enacted the measure for which Aristophanes had appealed» [Henderson, 2002: 3].

12 "And even if the Athenians did like the parabasis, that is a very short part of the play; why call for the whole play to be repeated just for that?» [MacDowell, 1995: 298].
} 
leged «advice» was given, accordingly, may also be supposed to belong mostly to that faction; otherwise, they would not need to be persuaded to rid themselves of Cleophon's leadership. But these men, too, must surely be supposed to regard those involved in the oligarchic revolution of 411 with great suspicion (which would also make Aristophanes' sarcastic characterizations of Theramenes apt for the audience). To characterize their efforts in the ways that Aristophanes does in the parabasis, accordingly, hardly seems to fit with what such audience members were likely to think. Would the democratic followers of Cleophon agree that the revolutionaries of 411 had simply been «tripped up by

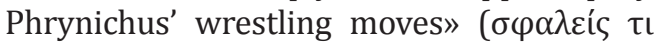

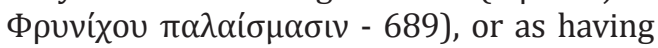

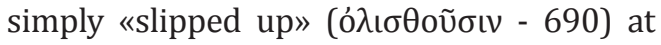
that time? Before we try to judge the content of Aristophanes' alleged «advice» to the Athenians, we might look more closely at the tone in which the advice is given.

Moreover, although Cleophon is treated with contempt during the play, that treatment pales in comparison to the vehemence of earlier insults Aristophanes managed to make towards Cleon and Lamachus ${ }^{13}$. Even if we suppose that the extremely rough days of Aristophanic insult are now past, what should we make of the fact that the last of Aristophanes' expressions of contempt for Cleophon lumps him in with a fairly diverse group of trouble-makers, including one known close associate of Alcibiades (Adeimantus son of Leucolophus - 1513, who would betray the Athenians at Aegospotomi) and at least one (Nicomachus - 1506) who Lysias (in Against Nicomachus) has in league with the oligarchs in the trial and execution of Cleophon ${ }^{14}$. Far from extolling the political virtues of his supposed oligarchic allies, at the very end of Frogs Aristophanes seems to have Pluto fondly wish that all of the most divisive political agents in Athens be sent straight to Hell.

Least of all, however, can any sensible account be made of the final specific advice that Aristophanes has the chorus leader give, which is that Athenian citizenship should be given to anyone who fights for Athens. Even given the precedents of the Plataeans and the slaves who had fought at Arginousae, the proposal to generalize such treatment to all who fought for Athens would be, as MacDowell puts it, «an astounding proposal» [MacDowell, 1995: 287].What makes the proposal «astounding» is presumably that «the enfranchisement of all slaves volunteering for naval service, if it had been made a permanent arrangement [...] would have produced a big drop in the number of slaves, and it is not surprising that the Athenians did not adopt this suggestion» [MacDowell, 1995: 287].

One might also wonder how are we to understand this advice as a consistent political advocacy that both shows contempt for «men of base metal, aliens, redheads, low fellows of low ancestry, johnny-come-very-latelys, whom formerly the city wouldn't have used lightly in a hurry even as scapegoats» (730733); (Sommerstein trans.), but also advocates for their being made citizens if they will only fight for Athens. Nonetheless, MacDowell sees the suggestion as a serious recommendation that Aristophanes would like to see adopted, on the ground that «The epirrhema welcomes foreigners and slaves for rowing and fighting in the navy, but the antepirrhema makes clear that such men are not welcome as leaders. A position of command needs a real Athenian» [MacDowell, 1995: 288], who MacDowell thinks must surely indicate Alcibiades [MacDowell, 1995: 297].

This explanation does not seem to me to be sufficient. Those with oligarchic sympathies (such as Aristophanes is imagined to have expressed in the parabasis) would surely not endorsed a proposal that would introduce a significant new influx of voters who would belong to the lowest end of the Athenian economy - at a great economic cost to their former owners, to boot. Those wanting an oligarchy established were very much opposed to continuing the war and were thus actively invested in trying to se-

\footnotetext{
${ }^{13}$ Also noted by MacDowell, 1995: 300.

14 Sommerstein doubts that Nicomachus was associated with the oligarchs [Sommerstein, 1996: 296], note on 1506). MacDowell accepts Lysias' account [MacDowell, 1995: 300].
} 
cure a peace agreement. The only reason to offer citizenship to slaves who fought for Athens, however, would be to secure advantage in continuing the war effort. If we assume that the parabasis provides an accurate account of Aristophanes' own political views, accordingly, we thereby convict him of gross inconsistency. Given his otherwise consistent response to the war-mongers in Athens' political ranks, the proposal to free slaves for their assistance in continuing what had become a disastrous war hardly seems like an oligarchic political fancy or as a political view ever elsewhere represented in Aristophanes' other works.

\section{A New Interpretation}

If my argument thus far is correct, the «advice» Aristophanes offers to his audience in the parabasis of Frogs is, in fact, wildly politically inconsistent. I contend that this is precisely how Aristophanes wanted it to appear. On the one hand, we have excellent reason to suppose that the idea of restoring those who had been disenfranchised was very much in the air as Aristophanes readied his play for production. The same may be said for replacing Cleophopn, which was quickly achieved soon afterwards with his execution. As for the final bit of «advice» we find in the parabasis, however, I suggest that a bit of speculation is in order. Those who continued to favor continuing the war effort surely knew that Athens was in desperate need for additional troops, especially for what remained of her navy. The proposal (whether it was ever made in an official setting) that slaves who fought for Athens should be given their freedom would cost the poorest Athenians little, but the richest would no doubt find it confiscatory. The argument that such a strategy had helped Athens achieve a victory at Arginousae (and anyway simply repeated an earlier decision involving the Plataeans, which had generally been regarded with favor in Athens) would be an easy one for a democrat to make ${ }^{15}$. So my sug- gestion is that this proposal, too, did not originate with Aristophanes, but was simply reported as yet another supposedly good bit of political advice by the chorus leader. In brief, I suspect that none of the political proposals that we find in the parabasis were actually Aristophanes' own brainchildren. Rather, I suspect that he is simply repeating to the audience various arguments and proposals that they had already been hearing from different partisans.

So why would Aristophanes have his chorus leader simply repeat the wildest and most extreme political proposals that I suggest were already familiar to his audience? If I'm right, the parabasis of Frogs is intended to hold a mirror up to the Athenians in the audience - to show them just how extreme and divisive politics had become in that dangerous time. Aristophanes is not recommending these foolish (and as was soon proven, ruinous) proposals to his audience. He is blending all of the most dangerous and foolish political extremisms into a stew of nonsense, and then presenting it to the audience to see how good it looks when served up in the theater. In that sense, he really is offering some advice to the audience, only very indirectly.

He is showing them that the kinds of ideas that many of them were actually now considering should be seen as madness from which they should immediately step back. By satirically mocking the insanities that too many of them were actually taking to be political wisdom, Aristophanes indirectly does what Pluto hopes Aeschylus will do when he returns to Athens: «Save our city with your good counsels and educate the foolish folk there, many as they are» (Sommerstein 1501-1503). Far from being «a willing tool or [an] innocent dupe» of the revolutionaries who would soon come into power, if I'm right, Aristophanes sounded appropriate warnings about just how dangerous both sides of Athens' bitterly divisive politics had become. Aristophanes was mocking - not endorsing - the follies that would soon prove to be so ruinous for Athens.

15 Indeed, the supposition that this was being proposed in Athens at the time might explain the haste with which the oligarchic faction acted in the weeks and months after the play was performed. The very idea of having most of their slaves freed could well have been the final straw in creating the tipping point that brought a swift (and ultimately brutal) end to the pro-war party in Athens. 


\section{References:}

Chantry, Scholia in Aristophanem III, Groningen, Egbert-Forsten 1994.

Dover K.J. Aristophanic Comedy. Berkeley and Los Angeles: University of California Press, 1972. 253 p.

Dover K.J. Aristophanes Frogs. Oxford: Clarendon Press, 1993. 398 p.

Griffith M. Aristophanes' Frogs. N.Y.: Oxford University Press, 2013. 320 p.

Henderson J. Aristophanes Frogs, Assemblywomen, Wealth. Harvard: Loeb Classical Library, 2002. 608 p.

Hubbard T.K. The Mask of Comedy: Aristophanes and the Intertextual Parabasis. Ithaca, N.Y.: Cornell University Press, 1991. 284 p.

Isocrates. On the Peace. Areopagiticus. Against the Sophists. Antidosis. Panathenaicus. Translated by George Norlin. Loeb Classical Library 229. Cambridge, MA: Harvard University Press, 1929.

Jacoby F., Die Fragmente der griechischen Historiker I - III, Berlin 1923.

Kassel R. and C. Austin, Poetae comici Graeci, Berlin 1983.

Lamb W. R. M. Lysias with an English Translation. Cambridge, MA: Harvard University Press/ London: William Heinemann, 1930.

MacDowell D.M. Aristophanes and Athens. Oxford: Oxford University Press, 1995. 376 p.

McDevitt A.S. Andocides 1, 78 and the Decree of Patrocleides // Hermes. 1970. № 98. P. 503-505.

Pseudo-Demostena: Deborah Kamen. Pseudo-Demosthenes: Against Neaira. Carlisle, PA: Dickinson College Commentaries: 2018.

Sheppard J.T. Politics in the Frogs of Aristophanes // The Journal of Hellenic Studies. 1910. № 30. P. 249-259.

Sommerstein A.H. Kleophon and the Restaging of Frogs // Talking about Laughter: And Other Studies in Greek Comedy / Ed. A.H. Sommerstein. Oxford UP: 2009. Available at: https://www.oxfordscholarship. com/view/10.1093/acprof:oso/9780199554195.001.0001/acprof-9780199554195-chapter-14 (accessed 29 October 2019).

Sommerstein A.H. Aristophanes Frogs. Oxford: Aris \& Phillips, 1996. 299 p.

\section{About the Author:}

Nicholas D. Smith - American Philosopher and James F. Miller Professor of Humanities and Professor of Classics and Philosophy at Lewis \& Clark College, 0615 S.W. Palatine Hill Road, Portland, Oregon 97219-7899, USA. E-mail: ndsmith@Iclark.edu (503) 768. 